\title{
A reflection on therapeutic futility: in Portuguese primary care context
}

\section{Mini Review}

The therapeutic futility can be defined as inappropriate and useless medical practices in relation to the advanced stage of the diseaseand may be characterized as the artificial prolongation of the dying process. ${ }^{1,2}$ In Portugal, there isn't, however a legal definition for therapeutic futility, there is a notion that health professionals must refrain from using procedures that prolong the suffering and diminish human dignity in the final stage of life. ${ }^{2}$

One of the principles of palliative care is based on the dignity of the human being repudiating the diagnostic and therapeutic futility. ${ }^{2}$ According to the Portuguese code of Medical Ethics, the doctor must refrain from practices not justified by the interest of the patient or to require or create false consumption needs. ${ }^{3}$

In palliative care, the decision to start or suspend a treatment is often an ethical dilemma and must be adapted to each phase of the disease cycle, implying effective communication between professionals, the patient and the family. ${ }^{4}$ The therapeutic futility must be set by the patient, he will be at the centre of the decision.

This approach implies that in an ideal context, palliative care is started according to the suggested in the "Transitional palliative care model". This model includes different types of care that patients with advanced chronic disease will require throughout the process, whether they are advanced cancer patients, whether it's severe organ failure or neurodegenerative diseases such as dementia. ${ }^{5}$

In the process of deliberation the opinions of the ethics councils are often useful, specially nowadays, when the doctor patient relationship paradigm tend to transit from a paternalistic relationship to enhance the patient autonomy principle. ${ }^{4}$

According to presented, the complexity of the phenomenon of therapeutic futility tends to be increasing. Currently, are observed in primary care patients whose functional decline period is prolonged. Throughout this period a number of issues are presented to health professionals.

When to suspend a pharmacological therapy that aims primary or secondary prevention of major cardiovascular events, such as antiaggregation and/or lipid-lowering therapy? Who should decide the family physician, the oncologist or the internist? What is the role of ethics councils? How to communicate with the patient and family about these dilemmas? How to take into account the patient's preferences at this stage of life?

Although a less frequent ethical dilemma in primary care setting the artificial hydratation and artificial feeding, which are often initiated in secondary health care, also concern the family health team for having direct implications in the care that the team will provide to the patient and the support provided to the family.

Often the role of the family doctor is not considered representative for the hospital teams in the deliberation on these procedures, although it is a fundamental element in the process of care assistance, understanding the patient and his will, and being the caregiver of the
Volume 3 Issue 3 - 2019

\author{
Nádia Neri Marinho, ${ }^{1,3}$ Joana Simões \\ Casanova ${ }^{2,3}$ \\ 'Family Physician, USF Caldas da Saúde, ACeS Grande Porto I, \\ Portugal \\ ${ }^{2}$ Family Physician, USF Oceanos, ACeS Matosinhos, Portugal \\ ${ }^{3}$ GEsPal's member (Palliative Care Study Group of the \\ Portuguese Association of General Practice and Family \\ Medicine)"
}

Correspondence: Joana Simões Casanova, Family Physician, USF Oceanos, ACeS Matosinhos, GEsPal's member (Palliative Care Study Group of the Portuguese Association of General Practice and Family Medicine), Portugal, Email j.simoescasanova@gmail.com, nadianerimarinho.mgf@gmail.com

Received: April 29, 2018 | Published: June 07, 2019

patient's family during the disease process and the grieving.

This point leads us to another important dilemma in palliative care, the suspension of treatment. There are several methodological proposals for the deliberative process, and all require a process of reflection on the richness and complexity of the reality of the patient in the end of life and his family. ${ }^{6}$

The satisfaction of the needs of the patient at the end of life seems to be related with the confidence in the doctor, the eviction of life extension with artificial means, the existence of effective communication, with the continuity of care, with accomplishing tasks and saying goodbye. ${ }^{7}$

Multidisciplinary teams and home palliative care seems to reduce symptom burden in particular for patients with cancer. ${ }^{8}$

The training, the information and reflection of all the professionals involved in the process of deliberation on therapeutic futility are fundamental. The knowledge of the ethical and legal aspects involved should be encouraged in this reflection. ${ }^{9}$

\section{Acknowledgements}

This manuscript had financial assistance from Liga Portuguesa Contra o Cancro - Núcleo Regional do Norte.

\section{Conflicts of interest}

Author declares there is no conflict of interest.

\section{References}

1. When life is not life. End of Life Decisions in Doctor-Patient Relationships. Raposo. Book of Proceedings of the 3rd Annual International Conference on Law, Regulations and Public Policy. 2016.

2. Direcção Geral da Saúde . Programa Nacional de Cuidados Paliativos. 2004. 
3. Ordem dos Médicos. Regulamento de Deontologia Médica. Diário da República, 2nd ed. Deveres dos médicos; 2016:22576.

4. Gutiérrez Javier Barbero. Manual para la atención psicosocial y espiritual a personas con enfermedades avanzadas. Catalunya: Obra Social "La Caixa". 2016.

5. Lynn Joanne, Adamson David M. Living well at the end of life. adapting health care to serious chronic illness in old age. Arlington: RAND health; 2003.

6. Zoboli, Elma. Bioética clínica na diversidade: a contribuição da proposta deliberativa de Diego Gracia. Revista Bioethikos. 2012;6(1):49-57.
7. Heyland DK, Dodek P, Rocker G, et al. What matters most in end-oflife care: perceptions of seriously ill patients and their family members. CMAJ. 2006;174(5):627-633.

8. Gomes B, Calanzani N, Curiale V, et al. Effectiveness and costeffectiveness of home palliative care services for adults with advanced illness and their caregivers. Cochrane Database Syst Rev. 2013;(6):CD007760.

9. White B, Willmott L, Cartwright C, et al. Doctors' knowledge of the law on withholding and withdrawing life-sustaining medical treatment. Med J Aust. 2014;201(4):229-232. 